\title{
The Influence of Promotional Strategies on the Performance of Nigerian Banks. A Study of Selected Banks in Nigeria
}

\author{
Ezu, Gideon Kasie PhD \\ Department of Banking and Finance, \\ Nnamdi Azikiwe University, Awka, Nigeria
}

\author{
Chris-Ejiogu Uzoamaka Gloria PhD \\ Department of Financial Management Technology, \\ Federal University of Technology, Owerri, Nigeria
}

\section{ABSTRACT}

The study examined the influence of promotional strategies on the performance of Nigerian banks. Survey research design was adopted in the study. A population of 120 top staff of UBA and Zenith bank was used in the study. The total population was used as the sample size of the study. Questionnaire was used as instrument of data collection and the data collected were analyzed using five scale likert and simple percentage. Chi-square was used to test the hypotheses. From the analysis, result showed that utilization of promotional strategies by banks highly improves their performance rate and that enables the bank to grow significantly. The finding also indicated that promotional strategies adopted by banks encourage customers deposit level and increases the rate of deposit as well as encouraging banks patronage hence, contributing to growth and performance of the bank. Based on the result, the study recommend that Banks that do not utilize promotional strategies should adopt and use them for better performance in their bank while those that are already making use of promotional strategies should also alternate or use other forms of promotional strategies different from what they use to have in order to increase the number of their customers and help retain them.

\section{Keywords: Branding, Outsourcing, strategy}

\section{INTRODUCTION:}

Marketing of financial services cannot be over emphasized because it ensures the survival of any firm or bank. Competition within and outside the shares of the country brought about by globalization and an improvement in customer awareness have made banks to use marketing as an important tool to increase returns, improve on the efficiency of the
Nigerian banking system and compete efficiently. As the economy develops and expands around the world, Nigeria is not excluded because there are fresh opportunities as well as threats that will give no chance for any aim chair banker or any banker who is not sound in marketing orientation. But, on the other hand, it will favour the advanced banker who is dynamic in his skills, frequently evaluating the internal and external environment, assessing his competitors, evaluating the threats and opportunities to his business and identifying new comers in the sector.

In order to remain in business, most banks strive to have an edge in the stiff competition going on in the industry by designing and implementing result on cited promotional strategies which would attract more potential savers to them which in return, increase the money available to them to carry out their business. Promotion is the direct way an organization such as a bank attempt to reach its public and is performed through the five elements of promotion mix industry advertising, sales promotion, personal selling, public relations and direct marketing. (Czinkota\&Konka, 2013)

Before the consolidation, most Nigerian banks concentrated on just the provisions of product and services to the detriment of consumers satisfaction. (Ogbeogie, 2007). It therefore means that they must be analysed through consumer's research and this information used to develop other marketing strategies and mix. However, the promotional programs coordinated must be part of viable market strategy and coordinated with other marketing activities. This is because a firm spends large sums on advertising or promotions, but it stands little chance of success if the product is of poor quality, 
contemporary marketing calls for developing a good product or service, pricing it adequately and making it available to the target consumers. Marketing promotion is an element of marketing mix which plays a vital role in the achievement of organizational goods. In other words, many banks recognize the need to interrogate other value marketing communication efforts such as media advertising, direct marketing, public relation and internet marketing to achieve more efficient marketing communication. Itheir fundamental aim is to persuade the active and potential customers of banks to transact business on continuous basis. In other to communicate well, banks often have advertising agencies to develop effective adverts, sales promotion specialist to develop corporate images.

Thus, the marketing communication must identify the largest audience, determine the response sought, choose and design the message. Thus, for the Nigerian banks to survive the staff competition that care with banking sector consolidation, there is need to design and complement well-articulated result orientation promotional strategies to remain liquid and competitive for enhanced performance.

The problem confronting the banking sector are multidimensional, eight local banks were reported in 2009 to be struggling to fix non-performing facilities in excess of 300 billion naira, part of which was given out as margin loans and the rest granted to petroleum product marketing companies owing to the cash in stock pieces and the cash in the price of crude oil in the international market and the dropping value of the naira(Flakpa,2009).However, lack of promotional activities by some banks has made them seem nonexistent and has also made them exclude the consciousness to their potential customers.

Promotional strategies engaged in by some banks failed to yield results which have made it difficult for them to compete favourably with other major players in the industry and have resulted to huge waste of resources. In order to strengthen their liability, position, and ability to compete favourably with other major players, those banks are designed and implemented to do business and strengthen their liquidity position and overall performance. Banks cannot survive without promotional activities because they must ensure that their customers and potential customers are aware of their product and services from time to time and remain in the consciousness of the general public. Without promotional strategies, the customer base of a bank cannot rise.

The main Objective of the study is to evaluate the influence of promotional strategies in Nigerian banking industry. Specially, the study will ascertain the extent zenith Bank and UBA banks effectively utilize promotional strategies to improve their profitability performance; Determine the extent the use of promotional strategies adopted by the banks impacts on the banks liquidity level and examine the extent customer perceived promotional strategies efficiency to affect the level of bank patronage.

\section{Hypotheses}

The following null hypotheses will be tested:

(Ho1): Zenith Bank and UBA Bank have not effectively utilize promotional strategies to improve their profitability performance.

H02): Promotional strategies adopted by banks does not impact on the banks liquidity level.

H03): The extent of promotional strategies adopted by banks as perceived by Customers does not affect the level of banks' patronage.

\subsection{Conceptual Review}

Strategy in the corporate world most times is formed as business strategy, corporate strategy, and competitive strategy. However it is formed, it certainly can be defined in different ways and some of the definition apply to every business, while other definition are applied in an organization with one other business unit.

Kolter (1996) defined strategy as " the board principle by which the business units expect to expects to achieve its marketing objectives in a targeted market. It consist of basic decision on total marketing expenditure, marketing mix and marketing allocation. To Charles and Gareth (1998) strategy as a specific pattern of decisions and actions hat man has take to achieve an organization`s goal.

Strategy can also be defined at the corporation level by Christensen and Andrews (1978) as a potter of decision in a company that shapes and reveals the objectives, purpose or goals. 
David (1992) defined strategy with six elements or dimensions, these includes the product market in which the business is to compete level of investment, the functional area strategies needed to compete in the selected product market, the strategic assets or skills that underline the strategy providing the sustainable competitive advantage (SGA), the allocations of resources over the business units and the development of synergistic effects, across the business.

Mini-Berg (1989) views strategy as one of the important function of management. He stated that strategy is making deals with the riches but on a wider sense refers to how collection system called organization establishes and if relevant, changes it basic orientation. Strategy is seemed to be concerned with the complex issues of collective intention on how organization is composed by many people.

\subsection{Theoretical Review}

The study is anchored on Uses and Gratification theory propounded by Katz in 1959. This theory argued that people (customers) are attracted to types of service or product and the types of content that satisfy their social and psychological needs. The Uses and Gratification Theory approach begins with the assumption that a product or services cannot have influence on an individual who has no "use" for it in the social and psychological context. The Uses and Gratifications Theory assumes that people's values, interests, associations, and social rules are pre potent and people selectively customize what they see or hear to these interests (Katz, 1959). The Uses and Gratifications Theory explains why and how people actively seek out specific product and services that satisfy their specific needs and would always stick to a product or services that best satisfy their need. The use of this theory in this study is appropriate in that when promotional strategies are used by banks, customers will always stick to the bank and patronize them, this in turn will contribute to the bank's performance.

\section{METHODOLOGY}

\subsection{Research Design}

Survey research design was used for this study. This research design is one in which a group of people or items are studied by collecting and analysing data from only a few people or items considered to be representative of the entire group (Nworgu, 2015). The survey design specifies how such data will be collected and analysed. This design is advantageous and considered appropriate for this study

\subsection{Area of the Study}

The study was conducted in Awka Anambra State. Anambra State is located in the south-east geopolitical zone of Nigeria and it occupies a land area of 4,416 square kilometres. The State has 21 local government areas for administrative convenience. The capital and the seat of government is Awka.

\subsection{Population of the Study}

The population of the study consisted of the top staff of UBA and zenith Bank staff in Awka south and North Local Government are of Anambra state. Data gathered from record department of the banks, put the number of staff at top staff of the banks in Awka at 120 as at November ,2017.

\subsection{Sample and sampling techniques}

In view of the fact that the population was small and manageable, the entire population was studied. Ali, Eyo and Sowande (2011) recommended that if the population is small, it should be studied entirely without sampling; therefore the researcher used the entire population as the sample of the study. The questionnaire was purposefully distributed to the respondents. In doing this 50 copies of the questionnaire was distributed to respondents in Zenith bank while 70 copies was distributed to respondents in UBA bank.

\subsection{Method and Sources of Data Collection}

A structured questionnaire entitled, 'the influence of promotional strategies on the performance of Nigerian Banks "was used as the main instrument for the collection of data. According to Sekaran and Bougie (2010), "Questionnaires are most useful as a data collection instrument, especially when large numbers of people are to be reached". This gives credence to the use of this collection tool as a means of collecting field data. The questionnaire was divided into two sections A and B. Section A sought information on personal variables such as gender etc. Section B was made up of three questions addressing each of research questions posed. Five (5) point scale as shown below was used to enable the researcher judge the respondents' level of confidence on each item.

\subsection{Method of Data Analysis}

Field data collected were all presented in tables and the personal data of the respondent was analysed 
using simple percentage while the research questions relating to the study were analysed using mean score. The hypotheses were tested using chi-square. The simple percentage response was calculated using the percentage formula shown below.

Percentage $(\%)=\frac{\mathrm{X} \times 100}{\mathrm{~W} 1}$

$\mathrm{X}=$ Total Number of respondent responses.

$\mathrm{W}=$ Total number of correctly filed questionnaires.

\section{Decision rule}

Any item with a mean value from 4.50-5.00 will be rated strongly agreed, 3.49-4.49, will be rated agreed, 2.49-2.50 will be rated disagree, $1.50-2.50$ will be rated strongly disagree while $0.01-1.50$ will be rated undecided. On the other hand, chi-square was used to test the hypotheses at $0.05 \%$ significance level. Null hypotheses will be rejected when calculated Chisquare value is less than tabulated critical level at $0.05 \%$ while it will be accepted when the calculated chi-square statistics is greater than the tabulated critical value.

\section{Data Presentation and Analysis}

Out of total of one hundred and twenty copies of the questionnaire distributed, three copies of the questionnaire were not correctly filled. Therefore, the researcher was left with 117 copies which were correctly completed and used for data analysis.

\subsection{Analysis of Data Related To Research Questions}

Research Question 1: To what extent have zenith Bank and UBA banks effectively utilized promotional strategies to improve their profitability performance?

Answers to this research question were sought using items 1- 7 on the questionnaire. The result of the analysis is presented in Table 6

Table 6: Respondents' Mean Rating' on the extent Zenith Bank and UBA banks have effectively utilized of promotional strategies to improve their performance

N= 117
\begin{tabular}{|c|c|c|c|}
\hline S/N & Items & Mean & Remark \\
\hline 1 & Promotional tools for bank performance & 4.0 & Agree \\
\hline 2 & The use of promotional strategies has led to higher rate of consumer satisfaction & 4.0 & Agree \\
\hline 3 & The use of promotional strategy has led to an improvement in the bank services & 4.0 & Agree \\
\hline 4 & $\begin{array}{c}\text { The promotional tools used by the bank has sustained their steady growth and } \\
\text { development. }\end{array}$ & 4.1 & Agree \\
\hline 5 & $\begin{array}{c}\text { The strategic marketing tools adopted by the bank has been effective and effective } \\
\text { in attracting customers. }\end{array}$ & 4.3 & Agree \\
\hline 6 & The promotional strategic adopted by the banks can be termed adequate. \\
\hline 7 & $\begin{array}{c}\text { The promotional strategically the disposed of the bank has been effectively } \\
\text { utilized. }\end{array}$ & 4.2 & Agree \\
\hline & $\begin{array}{c}\text { Grand Mean } \\
\text { Agree }\end{array}$ & $\mathbf{4 . 1}$ & Agree \\
\hline
\end{tabular}

Table 6 shows that the use of promotional strategies by zenith bank and UBA bank leads to promotional tools for bank performance, increases higher rate of consumer satisfaction and improvement in the bank services; help in sustaining a steady growth and development. The high mean value which are all above 3.0 is also a clear prove that the strategic marketing tools adopted by these banks have been effective in attracting customers and the promotional strategies adopted by the banks can be termed adequate and effective. The grand mean value of 4.1 is a further indication that these promotional strategies are significant in improving banks performance.

Research Question 2: To what extent have the use of promotional strategies adopted by banks impacts on the banks liquidity level?

Answers to this research question were sought using items 8 - 15 on the questionnaire. The result of the analysis is presented in Table 7 
Table 7: Respondents' Mean Rating' on the promotional strategies adopted by banks, it impacts on the banks and customers deposit Level

$\mathrm{N}=\mathbf{1 1 7}$

\begin{tabular}{|c|c|c|c|}
\hline $\mathbf{S} / \mathbf{N}$ & Items & Mean & Remark \\
\hline 8 & The use of promotional strategies to high patronage of banks by customers & 3.9 & Agree \\
\hline 9 & Promotional strategy profitability of the bank & 4.0 & Agree \\
\hline 10 & $\begin{array}{c}\text { The banks has attained a higher market share due to effective use of marketing } \\
\text { strategy }\end{array}$ & 4.0 & Agree \\
\hline 11 & The annual returns of bank have increased due to investment in strategic \\
marketing. & 4.9 & $\begin{array}{c}\text { Strongly } \\
\text { Agree }\end{array}$ \\
\hline 12 & Effectiveness of promotional strategy on the customers deposit & 4.0 & Agree \\
\hline 13 & $\begin{array}{c}\text { The bank has recorded higher depositor's interest with the use of strategic } \\
\text { product marketing }\end{array}$ & 4.0 & Agree \\
\hline 14 & $\begin{array}{c}\text { The strategic marketing of banks product/ services has increased the rate of } \\
\text { deposits as received from the public }\end{array}$ & 3.0 & Agree \\
\hline 15 & $\begin{array}{c}\text { The use of strategic marketing has increased the public awareness of bank } \\
\text { product and services }\end{array}$ & 4.0 & Agree \\
\hline & Grand mean & $\mathbf{3 . 9}$ & Agree \\
\hline
\end{tabular}

Table 7 shows that the use of promotional strategies use by banks have impact on the performance of the banks and customers deposit level. The impacts ranges high patronage of banks by customers, increase in profitability of the bank, the banks attaining higher market share due to effective use of marketing strategy, increase in annual returns of bank on investment and high level of customers deposit. The result of the findings further shows that the use of promotional strategies by the bank also led to increased public awareness of bank product and services. The mean value of each of the items and the grand mean value of 3.9 significantly indicates that these promotional strategies are highly significant in it positive effect on bank liquidity level.

Research Question 3: To what extent do customers perceive promotional strategies efficiency to affect the level of bank patronage?

Answers to this research question were sought using items $16-20$ on the questionnaire. The result of the analysis is presented in Table 8

Table 8: Respondents' Mean Rating' on the Extent Customers Perceive Promotional Strategies to Affect their level of Bank Patronage

$\mathrm{N}=117$

\begin{tabular}{|c|c|c|c|}
\hline $\mathbf{S} / \mathbf{N}$ & There is a relationship between bank strategic marketing and operational \\
profitability & $\begin{array}{c}\text { Mean } \\
16\end{array}$ & 4.0 & Agree \\
\hline 17 & There is a public awareness services through the use of strategic marketing & 3.7 & Agree \\
\hline 18 & $\begin{array}{c}\text { There is no need to improve the level of strategic marketing as employed by the } \\
\text { banks }\end{array}$ & 4.0 & Agree \\
\hline 19 & The bank customers has a positive perception of bank promotional strategy & 4.4 & Agree \\
\hline 20 & $\begin{array}{c}\text { Customers perception of the product as strategically promoted by banks can be said } \\
\text { to be satisfactory }\end{array}$ & 4.1 & Agree \\
\hline & Grand mean & $\mathbf{4 . 0}$ & Agree \\
\hline
\end{tabular}

Table 8 indicates that customers perceive promotional strategies to affect their level of bank patronage, such perceptions ranges from perceiving that there is a relationship between bank strategic marketing and 
operational profitability, public awareness services through the use of strategic marketing, no need to improve the level of strategic marketing as employed by the banks and banks customers having positive perception of bank promotional strategy. This result show that respondents may in one way or the other observed and noted the various perceptions of bank customers. Grand mean value of 4.0 also indicated that the result is significant.

\subsection{Hypotheses Testing}

Hypothesis one ( $\left.\mathbf{H}_{01}\right)$ : The performance of Zenith bank and UBA bank have no significant effect on the utilization of promotional strategies

\begin{tabular}{|c|c|c|c|c|}
\hline $\mathrm{S} / \mathrm{N}$ & 0 & $\mathrm{E}$ & $0-\mathrm{E}$ & $\frac{(0-\mathrm{E})^{2}}{\mathrm{E}}$ \\
\hline 1 & 4 & 3.9 & 0.01 & 0.0025 \\
\hline 2 & 4 & 3.9 & 0.01 & 0.0025 \\
\hline 3 & 4 & 3.9 & 0.01 & 0.0025 \\
\hline 4 & 4.3 & 3.9 & 0.16 & 0.0410 \\
\hline 5 & 4 & 3.9 & 0.01 & 0.0025 \\
\hline 6 & 4 & 3.9 & 0.01 & 0.0025 \\
\hline 7 & 3 & 3.9 & 0.81 & 0.2076 \\
\hline & & & & $\mathbf{0 . 2 6 1 1}$ \\
\hline
\end{tabular}

Significant level $=0.05 \%$

$$
\begin{aligned}
\mathrm{x}_{\mathrm{c}}^{2} & =0.2611 \\
\mathrm{x}_{\mathrm{t}}{ }^{2} & =12.59
\end{aligned}
$$

$$
\mathrm{N}=7: \mathrm{DF}=7-1=6
$$

At this level of significance (Calculated chi-square is-less than tabulate chi-square critical), Null hypothesis is rejected. This implies that promotional strategies of the banks significantly contribute the performance of the banks.

Hypothesis Two (H02): promotional strategies adopted by the banks do not impact on its customers deposit level.

\begin{tabular}{|c|c|c|c|c|}
\hline $\mathrm{S} / \mathrm{N}$ & 0 & $\mathrm{E}$ & $\mathbf{0}-\mathrm{E}$ & $\frac{(0-\mathrm{E})^{2}}{\mathrm{E}}$ \\
\hline 1 & 3 & 3.8 & -0.8 & 0.168 \\
\hline 2 & 4 & 3.8 & 0.2 & 0.015 \\
\hline 3 & 4 & 3.8 & 0.2 & 0.015 \\
\hline 4 & 4.9 & 3.8 & 1.1 & 0.318 \\
\hline 5 & 4 & 3.8 & 0.2 & 0.015 \\
\hline 6 & 4 & 3.8 & 0.2 & 0.052 \\
\hline 7 & 3 & 3.8 & -0.8 & 0.168 \\
\hline 8 & 4 & 3.8 & 0.2 & 0.015 \\
\hline & & & & 0.766 \\
\hline
\end{tabular}

Significant level $=0.05 \%$

$$
\begin{gathered}
\mathrm{x}^{2}{ }_{\mathrm{c}}=0.766 \\
\mathrm{x}^{2}{ }_{\mathrm{t}}=14.07 \\
\mathrm{~N}=8
\end{gathered}
$$

Significant level $=0.05 \%$

$$
\mathrm{DF}=8-1=7
$$


At this level of significance null hypothesis is rejected since calculated chi-square is less than tabulate chisquare critical value. Therefore, it means that there is significant impact of promotional strategies on banks and customers deposit level.

Hypothesis Three (Ho3): Customers perceived promotional strategies don not affect their level of bank patronage. .

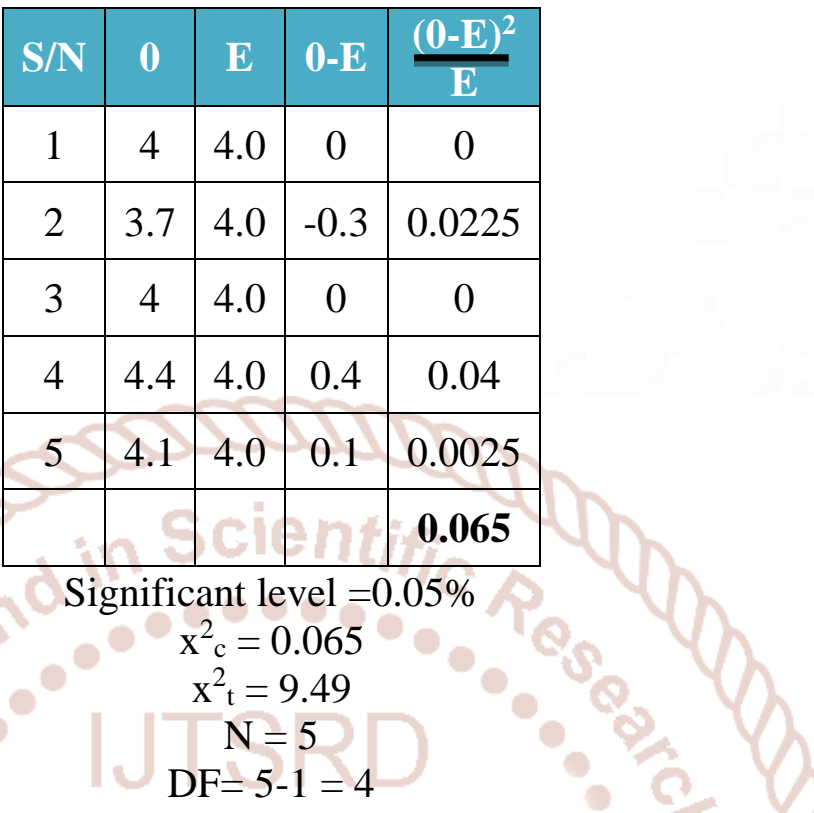

Null hypothesis is rejected at this level of significance since calculated chi-square is less than tabulate chisquare critical value. Therefore, it implies that Bank customers perceive promotional strategies to affect their level of bank patronage.

\subsection{Discussion of Major Finding}

The finding of the study showed that the utilization of promotional strategies by banks highly improves their performance rate and that enables the bank to grow significantly. The finding also indicated that promotional strategies adopted by banks encourage customers deposit level and increases the rate of deposit. The study also showed that the strategies encourages bank patronage hence, contributing to growth and performance of the bank. The finding of the study is also in consonance with the finding of Grankvist, kollberg and Peterson (2014) who in their study noted and said that that all elements of promotion mix are used to some extent in promoting banking services and such strategy have effect on their performance.

The finding corroborate the finding of Channon (2013) who in his study noted that promotion strategies attracts oriented consumer who are likely to switch bank rather than new account. The finding also agree with the finding of Andres and Srinvason (2013) who highlighted the importance of higher promotional strategies in increasing performance of banks in respect to their profit level.

\subsection{Summary of Findings}

The major findings made in the work among others include

1. The use of promotional strategies increase the profitability performance of banks.

2. The promotional strategies were noted to be effective in banks performance liquidity level to high extent.

3. Promotional strategies use by banks have positive impact on the performance of the banks and customers deposit level and customers perceive the promotional strategies to be adequate and encourage their patronage on banks.

\subsection{Conclusion}

Evidence from the findings of the study has shown that the promotional strategies utilized by banks such as zenith and UBA among others, contribute to the performance through various means. From the study, the use of promotional strategies by banks are viewed by customer to attract them into banking and depositing money with the bank. Therefore, it can be agreed that there is a strong influence of promotional strategies on the performance of banks in Nigeria. 


\subsection{Recommendations}

Based on the findings of the study, the study recommends the following,

1. Banks that do not utilize promotional strategies should adopt and use them for better performance in their bank. This will make the bank to attract the attention of customer therefore, encouraging them to patronize the bank.

2. Banks that are already making use of promotional strategies should also alternate or use other forms of promotional strategies different from what that use to have in other to increase the number of their customers and help retain them. When such is done customers to tend to appreciate the way through which the banks benefit them and will be encouraged to increase their level of deposit.

3. Promotional strategies that do not encourage the patronage of the banks should be change. This will enable the banks to be able to monitor the level of their growth and encourage customers to effectively patronize the bank.

\section{REFERENCES}

1. Achumba, I. C. (2000). Sales Management concept and strategies, Lagos. Man Williams publisher Ltd.

2. Achumba, I. C. and Osungwu L. (1994).Marketing Fundamentals and Practice; Rockhill, Al-marks educational research Inc.

3. Agbionu, U. C. (2005). Research in Business studies, Principles and Practice. Lagos. Clemenddy educational service.

4. Asika, N. (1991). Research methodology in Behavioral services, Ibadan Longman.

5. Asika, N. (2004). Research project made Easy - a simplified approach to writing and defending $a$ good research reports. Lagos. con-eight publishers.
6. Belch, G. E. and Belch, M. A. (2001). Advertising Communication perspective. $5^{\text {th }}$ Edition, New York. McGraw-Hill hwin.

7. Czinkota, M. R. and Radebough, L. H. (2004).International Business Environments and Operations. ${ }^{\text {th }}$ Ed. Upper Saddler River. N J.

8. Agbohungbe, O. B. (1995). Research methodology for Nigerian tertiary institutions; Lagos.Kole Consults.

9. Fiakpa, L. (2009). Glogal Financial Crisis. Nigerian Banks walk a tight rope. Business day Newspaper, September 19, 2009.

10. Kotler P. (1994). Marketing Management; New Delhi.Prentice Hall.

11. Kotler P. and Keller K. L. (2009).Marketing Management $13^{\text {th }}$ Edition. New Delhi, Prentice Hall.

12. Modern P. A. (1987).Elements of marketing. East heights harts, Dp publication Ltd.

13. Nigel, P. (1997). Market-led strategies change. Oxford, Bulteworth; Heinmann.

14. Odugbasan, O. and Osuagwu, I. (1996). Distribution channel management. Lagos. Mutugamu Nigeria Ltd.

15. Olujide, L. (2009). Marketing orientation and Business profitability in Nigerian Banking Industry; Journal of Department of Business Administration, University of Illorin, 3(3), 33-49.

16. Osuagwu, L. (2000). Business Research Method. Lagos. Grey Resources Ltd.

17. Umukoro, F. G. (1999). The concept of strategies in business management. Lagos. Concept publications.

18. Shokan, O. O. (1993). Research methodology. Lagos. Shokan investment company Ltd.

19. Station, W. J. (1983).Fundamentals of marketing. London. McGraw hill international.

\section{APPENDIX}

Instruction: Tick the Column like this $(\sqrt{ })$ for Option Which Best address your answer. Section A

1. Gender ------Male [ ] Female [ ]

2. Age ------ Below 26yrs [ ] 26-35yrs [ ] 45-55yrs [ ] Above 55yrs [ ].

3. Marital status ... Single [ ] Married [ ]

4. Educational qualification...WASE/NECO [ ] OND/NCE [ ] HND/B.sc [ ] M.sc/MBA [ ] PhD [ ]

5. Place of work.... Zenith Bank [ ] UBA Bank [ ] 
International Journal of Trend in Scientific Research and Development (IJTSRD) ISSN: 2456-6470

\section{Section B}

\section{Instruction: Tick the Column like this $(\sqrt{ })$ for Option Which Best address your opinion.}

1. To what extent do zenith Bank and UBA banks effectively utilize promotional strategies to improve their profitability performance?

\begin{tabular}{|c|c|c|c|c|c|}
\hline S/N & $\begin{array}{c}\text { Items on the extent zenith Bank and UBA banks Effectively utilization of } \\
\text { promotional strategies improves their performance }\end{array}$ & SA & S & A & U \\
\hline 1 & Promotional tools for bank performance & & & \\
\hline 2 & The use of promotional strategies has led to higher rate of consumer satisfaction & & & \\
\hline 3 & $\begin{array}{c}\text { The use of promotional strategy has led to an improvement in the bank services } \\
\text { The promotional tools used by the bank has sustained their steady growth and } \\
\text { development. }\end{array}$ & & & \\
\hline 5 & $\begin{array}{r}\text { The strategic marketing tools adopted by the bank has been effective and } \\
\text { effective in attracting customers. }\end{array}$ & & & \\
\hline 6 & The promotional strategic adopted by the banks can be termed adequate. & & & \\
\hline 7 & $\begin{array}{r}\text { The promotional strategically the disposed of the bank has been effectively } \\
\text { utilized. }\end{array}$ & & & \\
\hline
\end{tabular}

2. To what extent have the use of promotional strategies adopted by banks impacts on the banks liquidity level?

\begin{tabular}{|c|c|c|c|c|}
\hline S/N & $\begin{array}{c}\text { Items on the promotional strategies adopted by banks, it impacts on the } \\
\text { banks and customers deposit Level }\end{array}$ & SA & SD & A U \\
\hline 1 & The use of promotional strategies to high patronage of banks by customers & & & \\
\hline 2 & Promotional strategy profitability of the bank & & \\
\hline 3 & $\begin{array}{c}\text { The banks has attained a higher market share due to effective use of marketing } \\
\text { strategy }\end{array}$ & & & \\
\hline 4 & $\begin{array}{c}\text { The annual returns of bank have increased due to investment in strategic } \\
\text { marketing. }\end{array}$ & & & \\
\hline 5 & Effectiveness of promotional strategy on the customers deposit & & \\
\hline 6 & $\begin{array}{c}\text { The bank has recorded higher depositor's interest with the use of strategic } \\
\text { product marketing }\end{array}$ & & & \\
\hline 7 & $\begin{array}{c}\text { The strategic marketing of banks product/ services has increased the rate of } \\
\text { deposits as received from the public }\end{array}$ & & & \\
\hline 8 & $\begin{array}{r}\text { The use of strategic marketing has increased the public awareness of bank } \\
\text { product and services }\end{array}$ & & & \\
\hline
\end{tabular}

3. To what extent do customers perceive promotional strategies efficiency to affect the level of bank patronage?

\begin{tabular}{|c|c|c|c|c|c|}
\hline S/N & $\begin{array}{c}\text { Items on the Extent Customers Perceive Promotional Strategies to Affect } \\
\text { their level of Bank Patronage }\end{array}$ & SA & SD & A & U \\
\hline 16 & There is a relationship between bank strategic marketing and operational \\
profitability & & & & \\
\hline 17 & There is a public awareness services through the use of strategic marketing & & & & \\
\hline 18 & $\begin{array}{c}\text { There is no need to improve the level of strategic marketing as employed by the } \\
\text { banks }\end{array}$ & & & & \\
\hline 19 & The bank customers has a positive perception of bank promotional strategy & & & & \\
\hline 20 & $\begin{array}{c}\text { Customers perception of the product as strategically promoted by banks can be } \\
\text { said to be satisfactory }\end{array}$ & & & & \\
\hline
\end{tabular}

